NBER WORKING PAPER SERIES

NO ROOM FOR WEAK LINKS IN THE

CHAIN OF DEPOSIT INSURANCE REFORM

Edward J. Kane

Working Paper No. 2317

NATIONAL BUREAU OF ECONOMIC RESEARCH

1050 Massachusetts Avenue

Cambridge, MA 02138

July 1987

The research reported here is part of the NBER's research program in Financial Markets and Monetary Economics. Any opinions expressed are those of the author and not those of the National Bureau of Economic Research. 
No Room for Weak Links in the Chain of Deposit Insurance Reform

\begin{abstract}
Unrecognized and deferred losses at insured deposit institutions currently impair the capacity of the nation's principal deposit insurers (the FDIC and FSLIC) both to discipline failing institutions and to discipline or take over insolvent ones. These agencies' accrued but unreported losses far exceed their explicit financial resources. Moreover, their backlog of unresolved problem cases far exceeds the workload that their existing staffs can handle.

What holds the deposit-institution system together is financial-market participants' so-far-unshakable faith that politicians and bureaucrats cannot afford to let the FDIC and FSLIC renege on the obligations that they and their predecessors have permitted these agencies to assume. Underlying this belief is a conjectural economic assessment of the strength and constancy of incentives that direct elected politicians to bail out politically sensitive enterprises.

This paper addresses three tasks: (1) to clarify the defects in the information, monitoring, regulatory-response, and incentive sub-systems of federal deposit insurance that, by subsidizing institutional risk-taking, led so many deposit institutions and their insurers into economic insolvency; (2) to identify a generic mix of reforms that could in principle put the system right again; and (3) to explain how far proposals for reform that hold a place on the active legislative and regulatory agenda fall short of this ideal.
\end{abstract}

Edward J. Kane Reese Professor

Ohio State University

343 Hagerty Hall Columbus, Ohio 43210 


\title{
NO ROOM FOR WEAK LINKS IN THE CHAIN OF DEPOSIT INSURANCE REFORM
}

\author{
Edward J. Kane*
}

\section{Introduction and Summary}

After decades of successful operation, perverse risk-bearing incentives established by the federal deposit-insurance system threaten to engender a painful and expensive bureaucratic breakdown. This breakdown is foreshadowed in statelevel insurance-fund insolvencies experienced by Mississippi in 1976, by Nebraska in 1983, and by Ohio and Maryland in 1985. This paper stresses that the problem traces not just to inadequacies in FDIC and FSLIC premium structures, but more importantly to weaknesses in insurance agencies' policies and procedures for preventing, detecting, and resolving client insolvencies.

Deposit institutions officially fail when their chartering agency either closes them down or merges them out of existence. An unofficial failure occurs when the government takes direct or indirect control of a troubled firm. In the prototypical case, a failing deposit institution undergoes a gradual and time-consuming decline. As its financial condition deteriorates, government examiners give the firm a progressively lower rating in periodic examinations. When this rating becomes low enough, the firm is officially labeled a "problem institution" and subjected to very close regulatory supervision. This supervision, which is sometimes accompanied by subsidized federal loans or commitments, is meant to help the weakened firm control its losses and rebuild its capital accounts.

*The author is Everett D. Reese Professor of Banking and Monetary Economics and Research Associate, National Bureau of Economic Research. This research benefitted from the financial support of the National Center on Financial Services of the University of California, Berkeley and from detailed comments by George Benston and Paul Horvitz. Opinions expressed are the author's alone and should not be construed to represent those of NBER. 
In an average year during the 1970s, 8 banks and 4 S\&Ls failed and officials classified fewer than 2 percent of existing banks as problem institutions. During the 1980s, official and unofficial failures and problem cases surged dramatically. Beginning in 1985, de facto failure rates have averaged 2.5 per week for banks and 1.5 per week for S\&Ls. Currently, more than 10 percent of U.S. commercial banks and 20 percent of S\&Ls are regarded as problem institutions.

Unfortunately, deterioration in the profitability and net worth of deposit institutions and federal deposit insurers is even more acute than official figures indicate. Accounting gimmickry and forms of regulatory forbearance that depositinstitution supervisors routinely extend to many types of basket-case firms create or preserve fictitious profits and capital that today enable hundreds of financial institutions to operate in an economically insolvent or "zombie" state.

Unrecognized and deferred losses at insured deposit institutions currently impair the capacity of the nation's principal deposit insurers (the FDIC and FSLIC) both to discipline failing institutions and to discipline or take over insolvent ones. These agencies' accrued but unreported losses far exceed their explicit financial resources. Moreover, their backlog of unresolved problem cases far exceeds the workload that their existing staffs can handle. These financial and personnel shortages make it hard for the FDIC and FSLIC together to sustain a failure rate of more than four or five institutions per week.

On average over recent business cycles, defects in the deposit-insurance system are creating new problems for the FDIC and FSLIC faster than agency officials can resolve existing ones. With existing problems greatly exceeding explicit agency reserves, the continued credibility of FDIC and FSLIC financial promises is now conditioned more tightly on the outcomes of supporting political processes than on these agencies' innate financial strength. What holds the deposit-institution system together is financial-market participants' so-far-unshak- 
able faith that politicians and bureaucrats cannot afford to let the FDIC and FSLIC renege on the obligations that they and their predecessors have permitted these agencies to assume. Underlying this belief is a conjectural economic assessment of the strength and constancy of incentives that direct elected politicians to bail out politically sensitive enterprises.

Because it is not clear how long this assessment may be taken as given, this paper attempts three tasks. The first task is to clarify the defects in the information, monitoring, regulatory-response, and incentive sub-systems of federal deposit insurance that, by subsidizing institutional risk-taking, have brought so many deposit institutions and their insurers to their current sorry state. The second task is to identify a mix of minimally disruptive reforms that could in principle put the system right again. Finally, the third task is to explain how far proposals for reform that hold a place on the active legislative and regulatory agenda fall short of this ideal.

\section{Conceptual Foundations of Deposit Insurance}

To stop the deposit institution industry's continuing slide into financial insolvency, we need to shore up the foundations of the deposit-insurance system. These foundations differ fundamentally from the impression created by the statutory language on which the system is built. The de facto operation of federal deposit insurance differs radically from what its de jure features suggest.

Viewed as a generic financial contract, deposit insurance may be said to give "beneficiaries" a collection of "insurance services" in exchange for cash "premiums" disbursed by "paying customers." These insurance services are limited as to "coverage" and backed in combination by each insurer's cash "reserves" and "risk-management" and "loss-resolution" systems. Anomalously, in deposit-insurance contracts, each of the quoted characteristics diverges essentially from the meaning that an unsophisticated taxpayer would assign to them. 


\section{Who Pays? Who Benefits?}

The first irregularity is that the identity of de facto beneficiaries and paying customers are the reverse of the de jure ones. On the surface, deposit institutions pay their insurer a series of explicit premiums and make depositors the beneficiaries of the contract. At both agencies, the basic premium (which is subject to additional adjustment) is $1 / 12$ of one percent per year for every dollar of assessable deposits. ${ }^{1}$ However, the immediate benefits of the contract consist of reduced funding costs for institutions whose deposits are insured. FDIC and FSLIC guarantees permit insured firms to borrow at approximately Treasury yields to support a portfolio of risky assets that, in the absence of federal guarantees, they could finance only by paying a much higher interest rate. Moreover, explicit premiums constitute only a small portion of the total cost of keeping FDIC and FSLIC guarantees credible and most of these costs are borne ultimately by the taxpayer at large.

As illustrated in 1985 by the FDIC's suspension of premium rebates and by the FSLIC's introduction of a supplementary quarterly premium of $1 / 32$ of one percent, deposit institutions may be viewed as the taxpayers of first resort. As long as the need for additional reserves remains modest, supplementary premiums fall proximately on deposit institutions' capital. However, stockholders of assessed institutions need not shoulder this taxlike burden permanently. In competitive markets, regulatory burdens and taxes tend in large part to be shifted into the prices a firm offers its customers and the wages it pays its employees. Hence, supplementary premiums tend to tighten contract terms offered to depositors, borrowers, and deposit-institution employees. As ultimate payers for user charges and as the deep

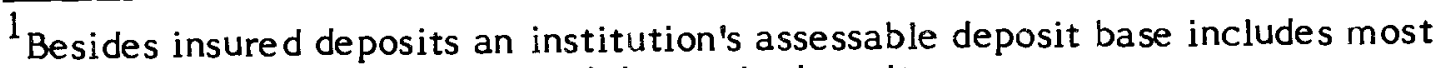
forms of its formally uninsured domestic deposits. 
pocket that backs up underfunded agency guarantees, nonstockholder citizens bear most of the costs of federal deposit insurance.

The heart of the underlying incentive problem is that taxpayers and politicians monitor the performance of federal deposit-insurance agencies in an unbalanced fashion. They are far more sensitive to de jure failures and de jure insurer outlays than they are to de facto ones. A de facto failure is best defined as a regulator-induced cessation of an institution's autonomous operations. A de jure failure occurs when the institution's charter is formally cancelled and/or transferred away from its current owners or managers by supervisory directive. When an institution's charter is cancelled, its accounts are thrown into some form of rece ivership. For this to occur, its chartering authority must render a prior finding of insolvency.

In a dictionary sense, an insolvent institution is one that has lost the capacity to discharge its liabilities. This capacity may be lost because of either illiquidity or economic solvency. A shortage of liquidity may render an institution with positive net assets temporarily unable to pay off its liabilities as they come due. However, as lender of last resort, the Federal Reserve is supposed to prevent mere liquidity shortgages from shutting down a deposit institution. Hence, the theoretically more relevant reason is the second one. In this case, the lack of capacity flows from the firm's entire balance sheet. It occurs when the value of the firm's assets falls below the value of its nonequity liabilities, so that the firm has "negative net worth."

The FDIC and FSLIC officially lose money in a client failure only when they absorb a former client's negative net-worth position into their own accounts. Because agency managers routinely resort to accounting gimmickry to disguise their true losses, it is necessary to distinguish also between insurers' de jure and de facto losses. A de facto loss occurs whenever the market value of an asset falls or 
that of a liability (such as an insurer's unbooked guarantee of client debt) increases. However, a de jure loss occurs only when and if FDIC and FSLIC choose to book a loss. FDIC and FSLIC discretion in booking losses is of course de facto rather than de jure. De jure, particular conditions can require agency accountants to recognize an incipient loss. However, agency managers prototypically tailor their responses to client insolvencies and deterioration in agency-owned assets to prevent undesirable requirements from taking hold.

Permitting agency personnel to conceal de facto economic insolvencies existing in the accounts not only of client institutions but also of their own agency permits them to mask accompanying deterioration in the contingent liabilities imposed on federal taxpayers. To protect taxpayers' interests, policymakers must be required to focus on the net market value of assets and liabilities. This market value is the criterion a private guarantor would use. In workout situations, this value serves as the fulcrum around which troubled private loans are restructured. It is not sufficient for federal insurers to employ definitions of institutional insolvency that turn on traditional accounting measures of net worth or liquidity. The readings these definitions generate may be consciously or unconsciously manipulated by bureaucrats and/or failing institutions in ways that serve these parties' particular ends at the expense of unwary and unguarded federal taxpayers.

The short-term liquidity of a troubled institution is often entirely in the hands of the Federal Reserve and Federal Home Loan Banks. As long as federal entities make and renew loans to an illiquid institution, the institution's managers can service current depositor claims. On the other hand, refusal to make or renew loans can force an illiquid but economically solvent institution into legal insolvency.

Accounting net worth is an inappropriate criterion because the book values at which accountants carry individual assets and liabilities are generally based on past 
acquisition costs. This approach to valuation permits an institution to increase its accounting net worth by selling assets on which it has unrealized gains in the form of post-acquisition price appreciation, while ignoring post-acquisition price declines and other forms of unbooked losses.

\section{Premiums versus Costs}

Deposit-insurance costs consist of expenses incurred to control and to reserve for the losses that the guarantor must reasonably expect to experience. Because federal guarantees are underpriced and explicit agency reserves are relatively small, the workability of the system depends on the effectiveness of constraints that insurers impose on insured institutions in hopes of keeping their risk-taking within acceptable levels. Hence, in addition to the opportunity costs of maintaining an insurance fund, deposit-insurance costs include expense engendered by monitoring and supervisory activity undertaken by insurers. They also include deposit institutions' explicit and implicit costs of complying with agency requirements. From a client's point of view, compliance costs constitute implicit insurance premiums. To calculate a firm's total premium, these implicit premiums must be added to explicit or cash premiums.

Because explicit premiums are subject to rebates and supplementary assessments, it is useful to distinguish between ex ante premiums (those paid in advance) and schemes of compensation that provide for an ex post (i.e., after the fact) settlement of claims actually brought against the insurer. Ex post assessments could be targeted much more selectively than they are now. One approach would be to require federally insured deposit institutions to be stockholder-owned and to extend the limited liability of individual deposit-institution stockholders to a multiple of the par value of their shares. Since mutual deposit institutions have been voluntarily converting to stockholder form at a rapid rate during the mid1980 s, the first part of this requirement is probably becoming less burdensome day 
by day. In the event an institution were to become insolvent, the second provision would make its stockholders personally liable for additional assessments. Extending stockholder liability would have the advantage of reducing the basic asymmetry in the distribution of the firm's gains and losses between stockholders and deposit insurers. To assure stockholders' willingness and ability to meet these assessments, personal and corporate deposit-institution stockholders could be required to bond their potential liability by placing a sufficiently valuable block of individually owned earning assets in escrow with the deposit institution or some other agent for the insurer. As with margin accounts that guarantee performance in futures trading, the total market value of escrowed assets would be what mattered, not their particular composition. Whenever a stockholder wanted to sell an escrowed asset, he would be free to replace that asset with another of like value.

Under existing arrangements, deposit insurers have the right to require stockholders of a troubled deposit institution to contribute additional capital. However, this right (or covenant) loses force as a firm becomes economically insolvent. As a firm's stockholder-contributed capital declines below zero, stockholders lose interest in paying a fee to stop the insurer from taking over the institution. This makes the timing of an insurer's call for additional capital the key to its enforceability. From this perspective, extending stockholder liability may be seen as a way to overcome bureaucratic lags in insurers' monitoring and response subsystems. It would reduce the criticality to insurers of recognizing and responding rapidly to a sudden deterioration in a client's economic condition.

To explore the burdensomeness of extending stockholder liability in this way, extended liability could be introduced as an optional way of meeting traditional capital requirements. Authorities could offer a lower requirement on paid-in capital for firms whose stock carries the prescribed form of direct call on stockholder assets. If capital requirements are to be increased, establishing 
flexibility in the ways that requirements can be met could prevent stiffer requirements from placing undue burdens on conservatively run firms. In small, closely held firms, stockholders can make sure that managers follow policies that keep the value of the call extremely small. At the same time, the insurer would be protected against sudden changes in a client's risk exposure over which it has no control.

Insurance Contract versus a Financial Guarantee

The existence of conjectural taxpayer backup and agency risk-management opportunities are two ways in which the term "insurance" misrepresents the nature of FDIC and FSLIC commitments. However, the most important difference is that these agencies' support is unconditional, and therefore not subject to actuarial analysis of the frequency with which specific contingencies have occurred in the past. True insurance contracts always designate a set of specific hazards against which coverage is written and a set of specific exceptions (e.g., wars or acts of God) against whose effects coverage does not apply.

Deposit-insurance contracts are financial guarantees. They place the credit of the FDIC and FSLIC behind that of their clients. A rational guarantor must establish and operate a risk-management system designed to control its risk exposure. Because FDIC and FSLIC guarantees apply irrespective of why an institution becomes unable to service its debts, their value is tied to the quality of these agencies' information, monitoring and response subsystems. The value of the guarantor's risk exposure in any firm can be defined as the difference between the capitalized value of the projected costs of monitoring and supervising clients and of resolving insolvencies (these costs are jointly determined since the insolvency rate per unit time is conditional on the effectiveness of the guarantor's riskmanagement system) less the capitalized value of client premiums. It is important to recognize that administrative opportunities exist for the guarantor to limit its 
losses by closing a client or taking over its operations before losses develop. This implies that the risk of not being able in timely fashion to exercise their options to close or take over failing firms is the major risk facing the FDIC and FSLIC. The existence of this risk explains the economic need for these agencies to establish appropriate information, monitoring, and supervisory (i.e., regulatory-response) subsystems to control this risk at minimum cost.

Active risk management is required because a fundamental asymmetry exists between the client's and the guarantor's claims to institution's unanticipated profits and losses. The degree of this asymmetry depends on the adequacy of the guarantor's information, monitoring, and response subsystems and on the relative financial strength of the guarantor and the client (i.e., each party's respective net worths and exposures to risk).

Implicit versus Explicit Insurance Reserves

Conjectural taxpayer backup gives insurers implicit reserves that far exceed their explicit reserve funds. Arrangements for closing holes that develop in FDIC or FSLIC balance sheets are incomplete. However, considerable evidence attests to the strength of incentives disposing elected politicians to bail out federal deposit-insurance agencies. First, Congress has permitted the FDIC and FSLIC to rely on the failing-firm doctrine to supplement their reserves by selling acquirers of failing firm exemptions from antitrust restrictions and from regulations against interstate and cross-industry operations. The failing-firm doctrine has been sorely stretched in the case of so-called phoenix S\&Ls (which represent combinations of failing firms in nearby localities) and in a Federal Home Loan Bark Board proposal to grant multiyear exemptions from unfriendly takeovers to acquirers of insolvent S\&Ls. Second, each agency owns a statutorily limited line of credit with the U.S. Treasury. Third, in March 1982 a Joint Congressional Resolution put the "full faith and credit" of the U.S. Treasury behind the FDIC and FSLIC. This resolution 
established no formal mechanism by which an illiquid deposit insurer could tap Treasury resources. Moreover, its legal force expired with the Congress that passed it. Nevertheless, it was used in 1985 to justify a nationwide advertising campaign (sponsored by a special-purpose industry foundation) that proclaimed that the full faith and credit of the U.S. government lies behind FSLIC guarantees. A prototypical ad is displayed in Figure One. To my mind, the failure of even a single Congressman or Senator either to issue a public denial or to urge the Federal Trade Commission to label these ads untruthful testifies to the existence of a backdoor equivalent of a full-faith-and-credit statute.

\section{Ine ffectiveness of Coverage Limitations}

A further anomaly is that the desultory approach to recognizing and resolving insolvencies at troubled firms employed by the FDIC and FSLIC extends de facto guarantees to formally uninsured liabilities of their clients. This extended coverage develops in two ways. First, when problems emerge at an individual institution, agency personnel tend to delay definitive action. This gives uninsured creditors, who are on balance more knowledgeable and more sophisticated than fully insured depositors, time either to move their funds or to develop liabilities to the problem firm that in most states can offset uninsured claims in the event of liquidation. During the interim, the implied outflows of funds may in part be financed by implicitly subsidized loans from the institution's Federal Reserve or Federal Home Loan Bank. Second, once an insolvency is officially recognized, the FDIC and FSLIC show a reluctance to close the institution and liquidate its accounts. Their preference is to arrange a live-firm acquisition that keeps all corporate contracts (including debt contracts) alive. These practices greatly reduce the probability that uninsured creditors suffer losses in a failure. They make a mockery of de jure limits set by statutory provisions meant to deny coverage to nondeposit debt and to deposit balances in excess of $\$ 100,000$. 


\section{THE FULL \\ FAITH AND CREDIT \\ OF THE \\ UNITED STATES \\ 离事

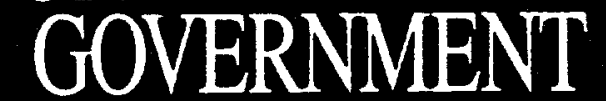 \\ STANDS BEHIND \\ THIS EMBLEM.}

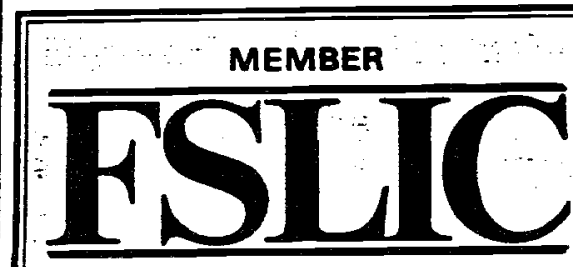

Federal Savings \& Loen Insurance Corp.

A U.S. Government Agency

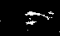

That's why you know your savings are safe, insured up to $\$ 100,000$.

Figure One

1985 Advertisement Suggesting That FSLIC Is Formally Backed Up by the Full Faith and Credit of the U.S. Government 
Political and bureaucratic pressure to keep institutions alive is particularly intense when problems occur at a very large institution or when a substantial number of clients are threatened simultaneously by a well-publicized common difficulty. Limitations on the resources and personnel available to deal with large or widespread problems reinforce authorities' propensity to temporize and to find ways to avoid straightforward recognition of agency losses. Important asymmetries exist between the slight criticism authorities have received for repeatedly bailing out formally uninsured parties and the extensive reputational damage angry uninsured creditors can inflict on agency leaders (damage that -- as 1985 experience in Ohio and Maryland demonstrates -- could become unbearably painful if the failure of a large institution or industry segment were to spread a loss of confidence onto other firms). Before uninsured creditors can be made truly to feel uninsured, a mechanism for informing taxpayers and institutionalizing their criticism would have to develop to correct this asymmetry in bureaucratic incentives.

Techniques of Insolvency Resolution and Loss Management

Alternative techniques for resolving a client insolvency differ principally in the extent to which managers, stockholders, and/or formally uninsured creditors are subsidized. Where subsidies occur, the techniques differ further in the extent to which actual and potential subsidies are hidden from taxpayer view.

Unsubsidized Approaches. The simplest way to resolve a client insolvency is for private parties voluntarily to invest enough additional capital in the enterprise to bring its net-worth account back up to regulatory standards. When this additional capital comes entirely from assessments levied against existing stockholders or from new equity issues sold in the securities markets, the adjustment is an unassisted recapitalization. Deposit insurers effectively sell all or part of the firm back to its stockholders. When the additional capital comes entirely from a new investor group seeking to purchase the deposit institution's charter, the 
transaction is called an "unassisted purchase and assumption." What is "purchased" is the institution's corporate assets and what is "assumed" is its corporate liabilities.

Whenever private investors prove unwilling to pay the insurer a positive price for the insolvent firm's charter, the insurer experiences a loss. It may resolve that loss in several ways. Conceptually, the most straightforward method is to pay off insured depositors and proceed as receiver to liquidate the corporation. In a liquidation and payoff, the corporation's assets are assigned to and managed by the insurer's liquidation division. This division collects the cash flows from asset sales, interest receipts, and loan repayments and allocates them to the firm's creditors more or less as it receives them. Until their claims are fully satisfied, the insurer and the uninsured creditors participate on a pro rata basis in all funds that are recovered.

When recoveries fall short of nonequity claims, the insurer and uninsured creditors are said to take a percentage "haircut," defined as the loss suffered per dollar of claims. Even when their claims are eventually paid in full, uninsured creditors suffer an interim loss of liquidity in that they lose their right to receive funds at the dates specified in their debt contract. Should recoveries in liquidation exceed nonequity claims, the excess would flow to the failed firm's stockholders.

To lessen uninsured creditors' loss of liquidity, deposit insurers have occasionally employed a variation of the liquidation-and-payoff technique in which the insurer pays uninsured creditors when the institution is closed a conservative estimate of the recoverable portion of their claims. In these "modified payoffs," the deposit insurer typically makes a second payment when the corporation's liquidation is completed, restoring a portion of the "financial hair" that uninsured creditors were initially assessed. 
Subsidized Approaches. Drawing on the metaphor of a foundering boat, popular usage employs the term "bailout" to describe situations in which the insurer subsidizes some combination of a failing firm's managers, stockholders, and uninsured creditors. In one way or another, important portions of ex ante and ex post deposit-insurance subsidies to failing firms are hidden from plain view. Taxpayer boats have been sailing alongside foundering deposit-institution vessels, but so far few taxpayers have noticed how much water deposit insurers have surreptitiously pumped into the bottom of their boats.

Although the fact of a loss is obvious in the case of an assisted recapitalization or takeover, the financial instruments in which the loss is encased (e.g., income-maintenance guarantees or exemptions from antitrust laws or burdensome regulations) often make it hard for outside observers to set an unambiguous value on the amount of assistance involved. Even less visible is the substantial market value that insurer and central-bank life support has for economically insolvent institutions. For an insolvent firm to have its deposit debt in denominations up to $\$ 100,000$ fully guaranteed by a federal agency permits and encourages it to undertake last-ditch risky plays at taxpayer expense. These desperate attempts to make a killing before the insurer can get around to resolving the insolvency have been likened to the length-of-the-field "Hail Mary" passes that football coaches face a parallel incentive to call during the last few plays of a losing contest.

To counter the incentive for insolvent firms to undertake risky endgame plays whose costs accrue asymmetrically to the guarantor, their managers are often required to sign a formal supervisory agreement with the insurer. Such contracts range from agreements to avoid a specific list of prohibited actions to requirements that force managers to clear all significant business decisions with the insurer before they may be undertaken. Given bureaucratic delays and bureaucrats' reluctance to approve even sound moves, subsidized financial life support that is 
accompanied by a strict supervisory agreement shades very rapidly into de facto nationalization.

Nationalization. De facto nationalization occurs when the affairs of the insolvent firm pass directly or indirectly under the control of a federal agency. As with firms operating under a strict supervisory agreement, insurers sometimes soften the fact of nationalization by: (1) disguising their ownership position as uncompensated forbearance or in options and warrant positions, and (2) by contracting with a third party to manage the firm. De facto nationalization has so far been conceived as a temporary step, meant to permit the agency to search for acceptable private bids for the institution's charter over a less pressing time frame. For example, this is the justification authorities offered in 1984 for the de facto nationalization of Continental lllinois which the FDIC achieved by taking a large options position in the firm's stock.

Reversing effective ownership positions has absorbed substantial time and effort. During the 1980 s, FSLIC has engaged in temporary de facto nationalization in two different ways. In 1982, the agency evolved the form of joint conservatorship known as the phoenix plan. This plan was employed in seven cases where it proved possible to combine several insolvent firms in a given regional market into a single corporation. Each phoenix corporation was recapitalized by FSLIC, which in turn appointed some or all of the firm's board of directors. In 1986, FSLIC may arguably be said to have reprivatized the last two of these institutions. But in the meantime, their place in de facto nationalization has been taken by roughly 60 institutions enlisted into a follow-up scheme known as the management consignment program. In this program, FSLIC appoints new directors and assigns the management of the corporation to a team of executives assembled by a healthy savings institution or other private contractor (which the insurer may have had to cajole or pressure into taking on the job). Although it usually does not formally 
recapitalize the successor corporation, FSLIC's deeper involvement in the firm conjecturally strengthens its informal guarantees. Both programs have the advantage of taking the original stockholders and managers of the failed institution out of the game, thereby permitting FSLIC to balance its pre-existing asymmetric position by taking over the upside of bets it is already guaranteeing. Such temporary trusteeships also permit a more graceful evaluation and unwinding of the troubled firm's detailed losses.

Because the universe of potential private buyers for individual institutions has proved restricted in practice, buying time to develop a reliable balance sheet makes a great deal of sense, particularly in reprivatizing large institutions. What doesn't make sense is not requiring insured institutions to develop and maintain such balance sheets as a matter of course. Moreover, it needs to be recognized that during periods of temporary nationalization formal linkage to the deposit insurer may give nationalized deposit institutions competitive advantages in particular markets and that interim managements face various conflicts of interest and strong incentives to pay an excessive price for deposit funds. Given FSLIC officials' own agency problems (exemplified by insurers' concerns for impeding the flow of information about their own operations to taxpayers), it is virtually impossible for them to write a management contract that can give an interim trustee a set of incentives that is fully compatible with the interests of the insurer. Finally, experience suggests that authorities seldom unwind the temporary nationalization of a large institution promptly. This is because squaring up such a firm's affairs almost never occupies an urgent place on the public agenda once it has been nationalized and is bound in any case to force the insurer to recognize explicitly some embarrassing losses. This argues for setting up a strict timetable for either liquidating nationalized positions or converting them into warrants. 
Link Between Deposit-Insurance Guarantees and Emergency Federal Reserve Lending

Deposit insurance serves two ostensible purposes. Microeconomically, it benefits depositors (especially small and unsophisticated ones) by undertaking the task of investigating and guaranteeing the credit of individual deposit institutions. This avoids duplication in credit evaluation by centralizing the process in a way that puts the FDIC and FSLIC into the collective shoes of what would otherwise be unprotected depositors (Black, Miller, and Posner, 1978).

The value of these services is clearly contingent on the policies that the Federal Reserve establishes regarding the access it affords illiquid and even insolvent firms to central-bank credit. To assure systemwide financial stability, central banks in every modern country are required to function as lenders of last resort to deposit institutions. They forestall actual and potential runs on illiquid individual institutions by standing ready to liquify their assets. They do this by accepting various of these institutions' high-quality assets as collateral for centralbank loans.

The Federal Reserve promises to lend on good collateral to any solvent deposit institution that experiences a run. The existence of this pledge means that deposit insurance is not necessary to prevent irrational runs on solvent institutions. From a macroeconomic point of view, deposit insurance functions as a redundant, fail-safe system designed to back up last-resort lending in case cautious Federal Reserve lending (as it did in the 1930s) either undermines or fails to preserve public confidence in deposit institutions.

\section{Why Deposit Insurance Needs to Be Reformed}

Incentive Asymmetries Are Undermining Public Confidence.

Federal deposit insurance currently subsidizes in a largely hidden way important categories of deposit-institution risk-bearing. These subsidies are rooted 
in two incentive asymmetries. First, deposit institutions face an incentive to "game" their federal guarantor. In effect, voluntarily increasing the riskiness of their enterprise increases the net value of the guarantee they receive. At the level of the individual firm, deposit-insurance subsidies to risk-bearing increase as the volatility of the firm's earnings increases and as the market value of stockholdercontributed capital declines. Second, elected politicians and regulators face similar incentives to game the federal taxpayer, by denying and concealing the full impact of unfavorable economic developments at insured institutions. Taken together, these incentive problems create a system of guarantees that over time has grown increasingly costly, unfair, dangerous, and unreliable.

These incentive breakdowns underlie multifold weaknesses in the depositinsurance scheme. To highlight systemic problems, it is useful to think of depositinsurance arrangements as a 50-yearold chain whose links have been weakened unevenly by the effects of age. Grouping individual links in the chain into four subsystems underscores the wide range of repairs needed to restore the chain to socially appropriate levels of long-run strength and reliability. First, techniques for measuring client and insurer performance make up an information subsystem. Second, techniques for gathering this information in timely fashion and tracking its implications for client and insurer risk exposure aggregate into a monitoring subsystem. Third, techniques by which federal regulators use this information to control client and insurer risk exposures constitutes a regulatory-response subsystem. Finally, costs and benefits generated by the first three subsystems and by weaknesses in parallel taxpayer systems for monitoring and critiquing the performance of the insurers create an incentive subsystem, which governs the behavior of all parties to the contract.

Defects in the incentive subsystem are intensified by weaknesses in the information, monitoring, and regulatory-response subsystems. Depositors that 
perceived themselves to be fully and perfectly guaranteed would have no incentive to guard against deposit-institution risk-taking. This concern would be transferred entirely to the guarantor. However, to resolve all doubt about the willingness and ability of the institution to live up to its obligations, depositors must also evaluate the financial resources and integrity of the guarantor. Whenever a possibility exists that the guarantor may not fully discharge its liabilities, depositors must look into the identity and strength of whatever parties effectively guarantee the guarantor. The back-up guarantors for federal deposit insurance are parties on whom regulators and legislators may be expected in a crisis to dump the financial burden of financing the agencies' shortfall. These potential ratepayers may be grouped into three tiers: (1) the stronger members of the pool of institutions directly covered by the troubled fund; (2) other close competitors of institutions in this pool, whom authorities may presume to derive some potentially taxable benefit from the associated exit of troubled firms from the market; and (3) the general taxpayer.

The more reasonable it seems to doubt whether federal insurers can service their contingent obligations from their own resources, the more reasonable it becomes to worry about how smoothly and effectively the political system could distribute the burden of recapitalizing them across the three tiers of back-up guarantors. When insolvencies in state-sponsored deposit-insurance corporations in Mississippi, Nebraska, Ohio, and Maryland revealed themselves in recent years, settlement of their outstanding liabilities was greatly delayed as back-up guarantors who professed to be surprised by their plight actively resisted legislative efforts to levy a share of the liability shortfall on them.

The hidden nature of deposit-insurance costs means that the liquidity of effective guarantees declines as aggregate guarantees grow relative to explicit agency resources. Empirical evidence for this notion may be found in the high 
deposit interest rates paid by zombie S\&Ls (Barth, Brumbaugh, and Sauerhaft, 1986) and the partial runoff of jumbo CDs at insured S\&Ls in late 1985 and early 1986. Rational depositors need to wonder about how aware the back-up guarantors are of their exposure and about how resistant these guarantors would prove if they were suddenly presented with a claim clearly stating their potential liability. Unjustifiable Expense of the System

The hidden cost of guaranteeing deposit-institution debt surged dramatically during the 1970 s and is still growing in the 1980s. First, increased volatility in the economic environment has made pre-existing guarantees more valuable and intensified risk-taking incentives at the margin. Second, secular trends in interest rates and in risk-taking have weakened managerial disincentives to risk-taking by reducing both industry capital and the incremental career risk inherent in go-forbroke loan and investment activity. Managers of decapitalized institutions learn to view themselves as minor-league Lee Iacoccas. Failing to revive their moribund firms can do little additional damage to their careers, but they can expect to reap great personal glory if in the face of fearsome odds they succeed in executing a winning strategy. Third, myopic insolvency-resolution policies followed by the FDIC and FSLIC have held harmless virtually all creditors of such large institutions as First Pennsylvania, Franklin National, U.S. National, Continental Illinois, and Financial Corporation of America. These policies have extended what the market perceives to be the effective coverage and perfection of conjectural guarantees at large institutions without at the same time establishing a mechanism for bringing the aggregate value of these guarantees back under control. Finally, although stating only an unenforceable sense of Congress that the full faith and credit of the U.S. Treasury stands behind the federal deposit-insurance agencies, a now-expired March 1982 joint Congressional Resolution reinforced market speculation that Congress ultimately stands willing to make good any de jure insolvency the depositinsurance agencies might experience. 
However, the de jure insolvency of a federal insurer could trigger a timeconsuming Congressional debate about loss distribution that might painfully prolong the associated bureaucratic breakdown. This possibility makes the existence of de facto deposit-insurer insolvency a matter of grave concern and creates a need to narrow the odds that one of the federal deposit insurers might actually experience a de jure insolvency. Making back-up guarantors clearly aware of the size and nature of their potential liabilities may be the only way to build a coalition for deposit-insurance reform. A key point in the case for long-run reform is the likelihood that informed taxpayers would not have been willing to accept the burden that misreported agency promises have inefficiently foisted upon them. Each successive increment in the perfection or extent of conjectural guarantees becomes increasingly expensive to attain. In their individual insurance transactions, taxpayers habitually select automobile policies that include deductibles and major medical and surgical coverages that include coinsurance elements and limitations on cumulative payouts. This shows individuals' informed response to the high incremental costs of supporting perfect coverages. It strains credulity to believe that parties willing to accept substantial amounts of risk everywhere else in their portfolios would knowingly choose to pay the freight for virtually perfect guarantees of the small subset of funds they and their fellow citizens choose to hold in bank and thrift deposits.

The inefficiency of perfect guarantees does not imply that they be phased out unintelligently. In particular, to walk away from them completely in the midst of a potential crisis would be extremely dangerous.

\section{Unfairness of Risk-Bearing Subsidies}

Deposit insurance only subsidizes client risk-bearing at the margin. Any institution that wished to operate risklessly would find the explicit and implicit premiums levied by the FDIC and FSLIC extremely burdensome. Deposit-insurance 
burdens decline and turn into subsidies as an institution's leverage and business risk increase. Inequities in the treatment of conservative and risk-seeking managements are even greater when we recognize that less-risky institutions provide the first two tiers of the system's back-up guarantees. Hence, a conservatively managed firm's de facto burden increases with the riskiness of its higher-flying (and more subsidized) competitors.

A second source of inequity comes from differences in the ways that insolvencies at large and small institutions are resolved. Except where large-scale fraud and defalcation create a substantial liability for undiscovered losses, deposit insurers have repeatedly proved themselves reluctant to liquidate large institutions. In such cases, keeping the corporation alive is administratively imprudent. The insurer would have to indemnify any new owner against a series of unassessable but potentially substantial claims. Using a phrase the Comptroller of the Currency used during Congressional hearings on the Continental-Illinois rescue, some institutions are seen to be "too large to liquidate." As long as insurers' resources hold out, uninsured creditors of such institutions expect to be held harmless from what we may call these institutions' wholly "honest" losses. This expectation makes the difference in value between formally insured and uninsured deposits in part a function of institutional size. Other things equal, a large institution receives a better guarantee of its debts than a smaller one. This means that capital markets must insist that smaller firms pay differentially higher interest rates on uninsured funds. At the same time, without federal guarantees small institutions might not be able to sell $\$ 100,000 \mathrm{CDs}$ in national markets at reasonable interest rates. Because insurers' information, monitoring, and regulatory-response subsystems fail to impose appropriate regulatory burdens on large and particularly foreign-financed institutions, in competing for large pools of funds small institutions' differentially poorer guarantee aggravates their natural disadvantage. 
Short-Run Unreliability

Deposit-insurance subsidies to risk bearing encourage go-for-broke behavior, whose consequences stand out most clearly in the case of "zombie" S\&Ls. Zombie institutions are those whose stockholder-contributed capital has become so negative that it is apt to describe them as examples of the "living dead." Like zombies in horror films, funds in these institutional corpses are capable of locomotion and tend to be put to malefic uses.

More generally, we may think of the financial sector of the U.S. economy as a minefield seeded with unexploded losses in institutional holdings of low-rate mortgages and in farm, construction, energy, and less-developed-country loans of poor quality. Secular expansion in the size of the minefield, in the density of the unexploded losses, and in their aggregate potential for financial violence is being driven by a defective deposit-insurance incentive system that is subtly undermining the systemic stability it is supposed to secure. The same defects in the system have helped federal guarantees to displace stockholder-contributed capital as the principal source of deposit-institution equity.

Inadequate FDIC and FSLIC risk-management systems and the absence of explicit arrangements for funding the pledge of Treasury faith and credit that is perceived to back the insurance funds open up the possibility of bureaucratic breakdown. Recent deposit-insurance crises in Ohio and Maryland demonstrate that a volatile and competitive financial environment can provide elected officials dangerous opportunities for misplaying a developing crisis.

Without a deep pocket into which to cram losses more or less as they occur, maintenance of public confidence in the insurance funds depends on maintaining public confidence that regulators and elected officials can deal with emerging problems in a roughly optimal manner. As mere human beings, government officials cannot prove equal to every task the economy puts before them. Hence, 
in any period in which the insurance agencies have become decapitalized, the system could break down any time.

\section{Long-Run Danger}

Although on any given day the probability of a bureaucratic breakdown remains extremely small, if the current system is maintained over the indefinite future, the occurrence of a breakdown seems nearly inevitable. Moreover, even if a breakdown can be avoided, the government is accumulating a growing equity stake in deposit institutions that amounts to a de facto and unintended nationalization. At a troubled or agressively managed firm, the market value of its FDIC or FSLIC guarantee looms much larger than stockholder-contributed equity. The value of any such guarantee may be conceived in either of two complementary ways, as the capitalized value of the interest saving the guarantee affords an insured institution or as the capitalized value of the net costs that supporting the guarantee imposes on the insurer. So that taxpayers can readily observe how well the FDIC and FSLIC control their risk exposure, guarantee values need to be estimated for every troubled firm and at least the aggregate value of these guarantees need to be reported by each guarantor agency. To protect taxpayers' interest, changes in the value of a firm's guarantee need to be made the focus of regulatory decisions about forbearance, closure, or recapitalization.

For policy purposes, the value of insurer guarantees needs to be recognized explicitly as an equity position and made the centerpiece of an energetic program of reprivatization. Disguising de facto nationalization as management-consignment, consent-agreement, net-worth-certificate, "phoenix plan," and regulatoryaccounting programs allows regulators and legislators to keep taxpayers from confronting honestly and in timely fashion the long-run costs of replacing private capital with government capital and of continuing to distort private decisions by a combination of subsidies to risk-taking and expanded bureaucratic intervention. In 
particular, misguided efforts to minimize accounting measures of the federal deficit while preserving FSLIC liquidity are simultaneously expanding and complicating the problems posed by zombie S\&Ls.

In the face of our nation's ideological commitment to free markets, it is both tragic and ironic to note that it may be on its way to nationalizing unintentionally a large segment of its deposit-institution industry. By failing to control the value of deposit-insurance guarantees, federal deposit insurers are making it increasingly likely that in the long run excercising their option to take over a large bundle of insolvent deposit institutions becomes the politically expedient way to balance taxpayers' equity interest in these institutions. The larger this nationalized industry segment turns out to be, the greater the potential waste of government operation and the larger the potential for corruption in its reprivatization.

\section{Developing a Workable Package of Subsystem Reforms}

Although federal deposit insurance worked well enough during its first thirty years, surges in economic volatility during the 1970 s and 1980 s placed it under increasing strain. This is because the federal deposit-insurance corporations adapted less rapidly and less completely to the changing economic environment than the institutions whose deposits they guarantee. Deposit institutions have expanded their aggregate access to subsidies by making obsolete various of the concepts and techniques by which deposit insurers have traditionally tracked, managed, and priced their risk exposure in client operations. FDIC and FSLIC managers have been slow to perceive (and even slower to counteract) the risk consequences of their clients' cumulative adaptation to change. Because corporate survival and employee jobs would have been on the line, a private guarantor would have innovated more rapidly and more symmetrically to offset the ways in which market developments and nontraditional client activities burdened its own profitability. 
As an organizing device, we may think of insurers and deposit institutions as engaged in a long automobile race. Whereas the deposit-institution cars are built to state-of-the-art specifications and maintained carefully, the insurers' cars show many weaknesses in design and maintenance. Insurer windshields (a metaphor for information subsystems) are caked with dirt and grease, making it hard for them to see where they and their rivals are going. Insurer driver seats (i.e., monitoring subsystems) are installed at right angles to the road, making their drivers have to strain even to process the information the dirty windshields make available. Third, braking, steering, and power controls on insurers' cars (i.e., regulatory-response subsystems) lack power-boosting and operate with distinct lags. Finally, the method of financing the race and awarding prize money creates an incentive subsystem that offers a much greater range of rewards to daring and skillful deposit-institution drivers and pit crews than their counterparts on the regulatory team can hope to attain.

Recognizing what is wrong with the existing system is the first step in planning improvements. As both the racing car and chain metaphors emphasize, to improve the deposit-insurance system we must strengthen each subsystem in balanced fashion. Along with the overlay of divergent political interests, the need for balance is what makes deposit-insurance reform such a tricky business.

Our analysis focuses on the effectiveness, feasibility, and opportunity costs of alternative components of subsystem reform. It seeks to underscore the need for research on identifying minimally disruptive combinations of reforms among which informed policymakers may reasonably choose.

Information Subsystem

The keystone of effective reform is developing a clean windshield, i.e., access to meaningful information on client performance and portfolio values. 
Authorities need to receive financial statements that convey the information that a rational private guarantor would want to receive.

Since 1938, generally accepted accounting principles (GAAP) have authorized deposit institutions to carry assets whose scheduled cash flows are relatively current at historical acquisition cost, even when these assets' market prices are known to diverge significantly from this book value. Novel and irregular regulatory accounting rules adopted by FSLIC in the early 1980 s (RAP) permit S\&Ls to treat some classes of debt to regulators as capital injections and to book unrealized gains over acquisition costs on selected classes of appreciated assets without having symmetrically to recognize parallel losses on depreciated items. Although RAP improves on GAAP by permitting appraised increments in value to be booked, in practice, by selectively ignoring appraised declines in value, RAP can be used to support an even more severe overstatement of a troubled firm's net worth.

For assessing guarantor risk exposure, either set of principles is inferior to market-value accounting, which requires that the carrying value of all assets and nonequity liabilities be marked to their current market values at the end of every accounting period. Market-value accounting further improves on GAAP and RAP by seeking to assign values to every element of what economists call the firm's "extended" balance sheet. Insurers' risk exposure varies with the capitalized value of all items capable of contributing positively or negatively to the firm's future income. Insurers need to treat the concept of an off-balance-sheet item as a contradiction in terms.

Because GAAP and RAP approve of omitting hard-to-value items and carrying even readily priced assets and liabilities at historical costs, they lend themselves to deceptive use when applied to financial institutions. To illustrate the distortion, let us contrast the effects of gimmicky sale-and-leaseback transactions in appreciated assets on GAAP, RAP, and market-value balance sheets. 
Such transactions increase a firm's capital under GAAP and would permit capital to be overstated under RAP (because the lease obligation need not be booked). Market-value accounting reveals that these transactions may actually weaken the firm by making deferrable gains on the price appreciation immediately taxable.

Suggestions for Change. Market-value accounting provides a reliable measure of firm performance in volatile times and sets up objective principles for measuring firm capital that are difficult for managers to manipulate with impunity. Marketvalue accounting requires managers and accountants to engage in potentially actionable fraud whenever they seek to create the appearances of profitability and of positive stockholder-contributed capital where these conditions do not truly exist.

To assess an institution's risk exposure properly, an accounting scheme cannot relegate important sources of risk to an "unbookable" category. That positions unrecorded by GAAP threaten deposit insurers is acknowledged by 1985 decisions imposing regulatory discipline on bank positions in standby letters of credit and daylight overdrafts. Similarly, if capital is to serve as a reliable criterion for tightening or loosening regulatory penalties, capital must be measured comprehensively. To let taxpayers see the true effects of deposit insurance on the capital of insurers and insured institutions, it is desirable to enter the aggregate market value of FDIC and FSLIC guarantees on the balance sheets of each agency. Recording these values as a liability to insurers would reveal a hole in insurer financing that is offset by unspecified claims on their back-up guarantors. Recording corresponding values as assets for insured institutions would reveal how large a role deposit-insurance guarantees play in maintaining the de jure solvency of firms threatened by large holdings of low-interest or poor-quality loans. When authorities permit firms to operate that are de facto insolvent, they implicitly waive covenants on client net worth that are meant to reduce the fundamental 
asymmetry in the guarantor's participation in the institution's future gains and losses. Unless an equity claim is created to balance the position, such waivers are transfer payments that supply equity funds on terms that become progressively more favorable as the extent of the firm's de facto insolvency increases. This is because the percentage of future losses that accrue to the guarantor increases as the firm's stockholder-contributed capital declines.

As financial innovations expand the universe of marketable instruments that are comparable to assets that do not actually trade, the feasibility of market-value accounting increases correspondingly. Appraisers can: (1) employ prices in secondary markets for comparable instruments, (2) use prices inherent in securitized obligations that are collateralized by cash flows from similar assets, (3) request that information be generated by insurer auctions of hard-to-value assets, (4) utilize the methods that investment bankers use to price takeover bids, and (5) draw on computer models linking movements in loan values to movements in prices of bonds that have similar features or that raise similar valuation issues. Finally, for franchise values and other intangible assets, the task of agreeing on objective valuation procedures can be assigned to a self-regulatory board.

Difficulties involved in instituting market-value accounting are almost entirely problems of transition. Careful financial analysts regularly attempt to translate a firm's records into market-value terms and most well-managed financial institutions already employ market-value accounting in internal evaluations of their own performance. While the resulting performance measurements are subject to some degree of inaccuracy, it is crucial to recognize that, on average (and especially for troubled firms), market-value readings provide more reliable measure of firm strength than either GAAP or RAP does.

Permitting or mandating market-value reports of performance to depositinstitution customers is a relatively low-cost way of improving market discipline on 
insureds and insurers alike. It would make the existing monitoring, response, and incentives systems work more cheaply, more fairly, and more reliably. Recognizing this makes it clear that the strength of industry and regulatory resistance to market-value accounting is a major obstacle to effective deposit-insurance reform.

The ad hoc alternative to market-value accounting has been to require footnotes to GAAP reports to communicate supplementary information describing "significant" changes in off-balance-sheet activities and unrealized gains and losses. The problem with this approach is that it assigns authorities rather than the market the task of deciding precisely when various potential sources of income and loss become "significant" enough to report. Such a system lengthens undesirable lags in adapting information flows to the realities of changing markets. Moreover, government and industry regulators have repeatedly signalled their willingness to help troubled deposit institutions to cook their books. The Financial Accounting Standards Board has opposed booking appraisal values and long tolerated booking the capitalized value of various fees as income exclusive of associated future costs. Moreover, the Board's Statement of Financial Accounting Standards Number 15 supports efforts to defer charging off losses on problem loans by requiring only that lenders restructure debt contracts creatively enough that future cash inflows on the restructured debt can be "reasonably estimated" to equal at least the principal value of the loan. These parties' willingness to help deposit institutions hide their losses from outside observers indicates how, in a discretionary reporting system, sectoral political pressures can overcome taxpayer and uninsured-creditor rights to know.

Monitoring Subsystem

We have likened regulators' information subsystem to a racing car's windshield and their monitoring subsystem to the angle at which a vehicle's driver's seat is installed. The issues in monitoring are how often regulators look through the 
windshield, whether they use technological opportunities to boost their vision to the 20-20 level, and what sort of problems they keep an eye out for.

Traditionally, agency monitoring efforts have focused on sending teams of field examiners at reasonable intervals to conduct an onsite examination of each client firm's accounts. Except in densely populated regions, agency examiners spend much of their working week on the road in unfamiliar and often hostile environments. Their principal tasks are to review financial statements (typically audited ones), to analyze the institutions' earnings and the quality of its loans and investments, and to evaluate the adequacy of the firm's management, liquidity, and capital. The information is pulled together in to a formal examination report that points out strengths and weaknesses in the firm's operation. In turn, this narrative report is summarized in a so-called CAMEL rating, which grades institutions on a five-point scale. The acronym CAMEL reflects the main categories of condition and performance on which client institutions are graded: capital; asset quality; management competence and integrity; earnings; and liquidity. Although the full report is presented to the institution's board of directors, only one federal agency (the FDIC) also gives the board the CAMEL grade, which is necessary to place the report in sharp managerial perspective.

Institutions whose CAMEL rating is 4 or 5 are labelled as "problems" and subjected to more frequent examination and special offsite scrutiny. Offsite monitoring looks at market data, public disclosures, and periodic reports filed with various regulators. To some extent, offsite analysis is also used as an earlywarning system to spot institutions that have encountered difficulty since their last examination so that the date of their next examination may be moved up.

Because troubled and aggressively managed institutions often seek to hide their problems from their auditors, customers, and regulators, it is not safe to take institutions' accounts and financial statements at face value. Although examiners are not specifically asked to examine for fraud, they sometimes detect it. 
Another class of monitoring complications concerns the difficulty of measuring the extent to which an institution is exposed to risk through the operations of associated firms. To minimize their net tax and regulatory burden, stockholders have found it advantageous to layer their ownership through holding companies and to locate activities that are taxed or regulated differentially in a series of carefully structured subsidiary and affiliated corporations. When a subsidiary or affiliated firm runs into trouble, it is hard for regulators to stop the resources of the regulated deposit institution from being used to bail it out. This difficulty makes it inappropriate to analyze the capital and balance sheet of a deposit institution independent from those of its related firms.

Suggestions for Change. In at least three respects, agency monitoring efforts are controversial. First, jurisdictional problems degrade the information flow. The resolution of jurisdictional overlaps has shifted the responsibility for examining important classes of institutions from the insurers who directly bear the risk inherent in client operations to state chartering agencies or to other federal regulators. It also creates blockages in the flow of relevant information among the multiple regulators. The task of minimizing these problems is assigned to coordinating bodies such as the Federal Financial Institutions Examination Council and the Conference of State Bank Supervisors (CSBS). Second, as financial innovation complicated the examination process and as the number of problem institutions proliferated, the size, training, and experience of the field examination force became progressively less adequate. This problem traces both to the vagaries of agency budget allocations and to agency or Office of Management and Budget unwillingness to pay-high-enough salaries or to establish a sufficiently attractive career ladder for examiners to overcome the lifestyle burdens of the job. Third, the nature of offsite and onsite analysis could be improved in obvious ways. In particular, critics would like to see examiners focus more sharply on 
fraud detection and make more use of electronic and remote means of analysis. It seems clear that greater emphasis on electronic reporting could reduce the number of weeks the average examiner would have to spend in the field and would diversify examiner activities and raise skill levels in ways that are likely to support higher profiles of career compensation. Examiner performance would also benefit from being more directly exposed to public second-guessing. Knowing that examiner evaluations could be criticized by outsiders and compared with those of private rating agencies would put pressure on agency managers to reduce what is now considerabie idiosyncratic variation in the quality and character of individual examinations.

During the last two years, federal regulators have to some degree responded to all of these criticisms. In May 1986, federal bank regulators agreed to share supervisory information with state supervisors. Similarly, in the face of a growing interstate extension of state-chartered firms, CSBS is urging the states to develop mechanisms for sharing supervisory information among themselves. At the federal level, insurers' jurisdiction over problem institutions has been expanded. Federal regulators have also begun to enlarge their examination force and to make better use of deposit-rate and other available data to target their examinations. The change is especially marked at the Federal Home Loan Bank Board (FHLBB), which in July 1985 moved its examination function off-budget to the Federal Home Loan Banks and doubled the authorized size of the system's examiner workforce. Before these moves took place, whereas the federal banking regulators had more than two examiners for every five FDIC-insured firms, the FHLBB had only about one examiner for every five FSLIC-insured institutions. Because the pool of skilled and experienced examiners is far smaller than the number of available positions at the different agencies, curing the shortage of able examiners depends on regulators' success in attracting qualified personnel from related fields and in establishing 
appropriate programs for training examiners. Finally, the possibility of following the FDIC's lead in releasing examiner ratings to directors is at least being discussed at other agencies and the possibility that institutions may someday be permitted to advertise examination ratings no longer seems farfetched.

Regulators and trade associations reveal a strong preference for accounting principles that convey options to conceal material facts. While this preference keeps the regulatory windshield almost as dirty as ever, improvements in agency monitoring subsystems have encountered far less political opposition.

Regulatory-Response or Enforcement Subsystem

At institutions for which adverse trends and potential losses have been identified, the problem becomes one of bringing the insurer's exposure in these firms back under control. Corrective pressure can be generated in either of two complementary ways, either implicitly by reinforcing market discipline or explicitly by increasing regulatory discipline.

Market discipline concerns penalties that the market imposes on managers, stockholders, and uninsured creditors. For regulators, reinforcing market discipline is mainly a matter of making or at least permitting timely disclosure of material facts to depositors and other customers who see themselves exposed to loss. As the proviso makes clear, unless deposit-insurance guarantees are seen to be imperfect or incomplete, this discipline cannot operate at all. It is in this sense that reforms in the insurance contract such as lowering de jure account coverage below $\$ 100,000$ or introducing deductibles, coinsurance, or lifetime limits on depositor recoveries can be said to enhance market discipline. Considered as a test of the feasibility of generating depositor discipline by curtailing de facto bailouts of uninsured creditors, the eight modified payoffs that the FDIC conducted in early 1984 were enormously successful. The efficacy of this exploratory policy is evidenced by the run on Continental Illinois that followed close upon the experiment and scared authorities into abandoning their use of this procedure. 
Capital requirements and activity limitations hold the key role in generating regulatory discipline, but a range of other policy tools exists. These tools may be thought of as ways of adjusting deposit-institution cars to make them slower or less maneuverable. Regulators' rights to tailor adjustments to individual situations are tempered by legal and political constraints. Client institutions are entitled to due process, which means a right to formal notice, private evidentiary hearings, and subsequent appeals. A May 1986 decision by the U.S. Circuit Court of Appeals held that, even with a favorable ruling from an administrative law judge, the Comptroller of the Currency cannot levy penalties against bank directors without also going through the U.S. District Court system. In principle, regulatory mechanics cannot safely touch a deposit institution's car until they have won either a court order or a negotiated settlement. In practice, regulators' ability to release information that could prove embarrassing to client managers often helps to intimidate problem firms into settling rather than litigating proposed regulatory actions.

The least oppressive type of settlement agreement between regulators and client managers is known as a memorandum of understanding or letter agreement. As seen in the State of Ohio's repeated failure to win compliance with such agreements from Home State Savings, letter agreements are not strictly enforceable in the courts. Unscrupulous institutions can persist in the behavior they have agreed to eschew, safe from specific penalty. However, having made and violated such agreements puts an institution at a severe disadvantage in fighting formal enforcement actions.

In recent years, the number of more formal actions has trended sharply upward with the number of problem institutions. In order of escalating impact, these tougher actions include: directives to raise additional capital within a fixed period of time, cease-and-desist orders; fines levied on officers, directors, and negligent outside auditors; actions to remove particular officers or directors; and 
proceedings to terminate insurance. Although individual problem institutions have little scope for winning relief either from prevailing capital requirements and activity restrictions or from specific directives to raise additional capital, the three actions listed next are usually embodied in negotiated "consent agreements," in which (as in a plea bargain) client managers typically give up their right to contest the action in exchange for a favorable adjustment in the penalties to which they are exposed. Because proceedings to terminate insurance take up to two years to complete, their main value to regulators is to serve as a bargaining threat. This threat is enhanced by the disruptive influence that instituting formal proceedings can have on the institution's liquidity. A dimunition in liquidity would strengthen the insurer's hands by making it easier to have the problem firm declared legally insolvent.

The ultimate enforcement action is a declaration of insolvency by the chartering authority, which usually authorizes the insurer to wrest control from existing managers and stockholders. The range of techniques available for resolving insolvencies is reviewed in section II of this paper.

Suggestions for Change. To control client risk-taking, the current response subsystem relies almost exclusively on bureaucratically administered regulatory restraints (as opposed to market discipline). In this same vein, new regulatory powers and improved monitoring subsystems form the dominant elements of reform proposals currently receiving official consideration. That hopes can be raised high by out-of-balance reform proposals testifies to voters' naive and inappropriate trust in the capacity of bureaucrats to hold the system together against the relentless forces of a disequilibrium administrative price for risk-bearing services.

These proposals seek to develop new opportunities to discipline clients and greater freedom to wind up the affairs of problem institutions. Acting under existing authority, regulators have proposed to raise existing capital requirements 
and to institute systems of risk-rated explicit premiums and risk-rated capital requirements. Although the burden of these systems would vary with perceived riskiness of individual institutions, so far no agency has formally linked its proposals (as economic research would dictate) to estimates of the market value of the guarantee services each institution receives.

In addition, various of the regulators have asked Congress for three types of new authority: to take over "failing" as well as insolvent firms, to charge problem institutions for costs of increased supervision, and to terminate insurance more quickly. The FDIC is also interested in winning increased supervisory authority over banks that belong to the Federal Reserve System and in attaining passage of a statute that would give depositors in FDIC-insured banks preference in liquidation over all other types of creditor.

Thinking of deposit insurance as a chain shows that inadequacies in regulators' information subsystem cannot be fully counterbalanced by enhancing their enforcement powers. It is clear is that, in the absence of information reforms, enforcement powers must be expanded greatly before they can even appear to have much impact on the flow of unintended subsidies. For example, because a marketvalue test for insolvency is not being requested, authorities want the right to close failing firms and the right to decide for themselves on the basis of unspecified criteria whether or not a firm is "failing." However, such a scheme may occasionally lead to the closure of sound firms and gives sectoral political pressures for forbearance maximal opportunity to preserve unsound ones. It is imprudent to plan to substitute regulators' judgment for market-based measures either of what capital is or of what percentage capital requirements ought to apply to different kinds of balance-sheet positions. In cases where the effective marginal requirements exceed the fair market value of guarantee services, the relevant business would tend to flow to uninsured institutions. On the other hand, activities for which the requirements are too low would find themselves subsidized. 
Politically, unless a serious crisis develops, it is unrealistic for federal regulators to expect to win such sweeping discretionary powers. Even though a majority of the members of industry trade associations want to see high-flying competitors brought under control, they have lobbied energetically against legislation that would grant regulators the authority to close institutions whose operations come into disfavor. Managers and stockholders of even conservatively run institutions fear that somewhere down the line such powers would be wielded abusively.

Deposit insurers' risk management is strategically defective. It needs to be reorganized in ways dictated by the common-sense principle of defensive symmetry. This principle holds, for example, that a defensive basketball player balance his weight and arrange his limbs in ways that create a mirror image of the offensive player he is guarding. In this way, the defensive player can move with his opponent laterally and diagonally to cut off sudden drives to the basket. This principle tells us that, when economic volatility forced deposit institutions to set up sophisticated asset-liability committees (ALCOs) to monitor and control their own risk exposure, federal deposit insurers would have benefitted from setting up symmetric committees of their own and supported them with parallel information and planning systems. The job of these systems would be to analyze at frequent intervals the implications for extended agency balance sheets of risks taken by members of a representative sample of client institutions. On the basis of this analysis, unwanted positions that client behavior opened in each insurer's extended balance sheet could be promptly identified and closed by offsetting investments ordered by the agency's ALCO.

For the taxpayer, a further advantage of this strategy is that unwinding unwelcome risks by explicit transactions would convert unintended deposit-insurance subsidies into explicit expenses. Rather than hiding as off-budget items, 
inadvertent subsidies to risk-bearing by individual clients would raise agency operating costs. Resulting agency deficits would alert politicians and the public of the need to recalibrate explicit and implicit deposit-insurance premiums.

Insolvency Resolution and Pressures for Capital Forbearance. Pressures for capital forbearance underscore the collision between regulators' duty to protect taxpayers' economic interest and bureaucratic incentives to favor politically strong regional or sectoral interests. Capital forbearance occurs when regulators explicitly lower minimum capital requirements for decapitalized institutions (i.e., those from whom deposit-insurance reserves most need protection). A policy of simple forbearance waives a series of valuable covenants in insurance contracts without exacting any quid pro quo. During the last decade, capital forbearance was routinely extended to hundreds of troubled S\&Ls and mutual savings banks. In principle, this policy "buys time" for troubled institutions to resolve their problems on their own. In practice, unless insurers take a balancing equity claim, capital forbearance is myopic. As the continued deterioration of zombie S\&Ls demonstrates, decapitalization encourages last-ditch plays by insolvent institutions and tends to result in larger overall economic losses for the insurer.

Prior to March 1986, the FDIC held firmly to a policy of covenant enforcement for commercial banks. As political pressure to ease the strain on agriculture and energy banks became intense, federal banking regulators stated their intention to permit capital accounts at selected banks (those that are "wellmanaged") to sink below minimum standards without triggering closer regulation and to help these firms to defer charging off losses on restructured loans. Banks that receive forbearance may operate with a ratio of primary capital to assets as low as 4 percent and take up to seven years to raise this ratio back to the ordinary 5.5 percent norm. However, the details of different agencies' programs are less important than the force of Congressional efforts to make sure that the need for regulatory forbearance was communicated all the way down to the examiner level. 
Tougher insolvency. resolution requires that the lender of last resort avoid lending to insolvent institutions and that decision to pull the plug on individual firms be given greater insulation from political pressure. To strengthen the deposit-insurance agencies politically, they must first be strengthened financially. They must be assigned sufficient resources to support the charge-offs inherent in taking over client institutions before their capital is exhausted. They must also receive enough budgetary freedom to hire the staff they need to carry out the tasks of enforcing solvency requirements and bridging the operation of decapitalized firms until private acquirers or investors can be found. To make sure that solvency decisions are objective and economically based, authorities and industry leaders must accept a more meaningful concept of legal insolvency. The criterion developed must focus on the market value of stockholder-contributed capital. Insolvency cannot be permitted to turn on an institution's liquidity, because liquidity either is conveyed by federal deposit guarantees or, in truly severe cases, becomes a function of discretionary eligibility criteria laid down by the lender of last resort. Nor can the test be permitted to focus on traditional accounting measures of a firm's net worth, because this value too is favorably impacted by federal guarantees and because existing accounting rules leave firms and regulators considerable opportunity to conceal evidence of de facto insolvency.

\section{Incentive Subsystem}

The incentive subsystem comprises the collection of benefits and costs that reward and punish particular kinds of behavior by parties that are directly or indirectly involved in depositinsurance contracts. These parties include politicians, insurance-agency personnel, managers and stockholders of insured deposit institutions, deposit-institution depositors and borrowers, and federal taxpayers. Defects in this system offer individual deposit-institution managers, stockholders, and customers above-market rewards for engaging in administratively underdisciplined types of risky transactions and create a flow of rents to politicians and regulators for suppressing information about the consequences for taxpayers of the risks and bailouts that are undertaken. 
Possibilities for Change. Different parties to the deposit-insurance contract possess different sets of information and exercise different degrees of control. Reducing the risks to the system therefore requires incentive compatibility between government agents (politicians and regulators), their principals (taxpayers), and deposit-institution managers, stockholders, and customers.

Several changes in the structure of the deposit-insurance contract could improve incentives for depositors to monitor and respond to changes in a deposit institution's risk exposure. The simplest class of adjustments would be to roll back maximum accountholder coverages. Coverage rollbacks can be explicit or implicit. Implicit rollbacks aim at making statutory coverage limitations more credible. This could be accomplished, for example, by enacting a depositor-preference statute or adopting a policy of using modified payoffs for large-bank failures. Explicit rollbacks would alter the terms of deposit-insurance guarantees in one of five ways: reducing formal coverage limits; introducing a structure of participating coinsurance that would require depositors to participate in realized losses (with the rate of participation tied, for example, to account size or to the excess of an institution's offering rates on CDs over yields on Treasury securities of similar maturity and liquidity); incorporating a deductible into losses in excess of some relatively nominal threshold amount; establishing lifetime limits on the amount an individual can collect from federal deposit insurers (to be monitored by the Internal Revenue Service); or constraining contractually the riskiness of the activities that an insured institution may undertake. The purpose of these reforms would be to reduce the completeness of depositinsurance coverage for depositors that are large and sophisticated enough to protect their balances at lower social cost than federal regulators can.

Stockholder and insurer interests could be made more compatible by requiring changes in the ownership structure of insured institutions. These changes consist of requiring insured deposit institutions to be stockholder-owned by some target date and extending the liability of stockholders in insured institutions in bonded fashion to a multiple of the par value of their position in the firm. Because mutual deposit institutions are increasingly converting to stock status voluntarily, the burden of converting the remaining mutual institutions is falling rapidly. 
Bonding, which is required to ensure prompt collectability, may involve nothing more complicated than maintaining in escrow with the institution or some other agent for the insurer a collection of earning assets of assured value. Extending depositor liability promises to reduce the value of deposit-insurance guarantees by establishing contingent claims on stockholders. Because the ex ante value of FDIC rights to impose post-failure or other ex post assessments would increase with an institution's leverage and other kinds of risk exposure, resulting declines in deposit-institution stock prices would prove roughly proportional to market ratings of the firm's riskiness. These stock-price changes constitute the transition cost of reform. Extending stockholder liability at insured institutions can be interpreted as a risk-rated increase in the effective insurance premium that is ex post in nature. Impounding the call feature into depositinstitution stock prices would transfer deposit-insurance subsidies back to the taxpayer and change incentives for stockholders, managers, and depositors.

Proposals to increase the risk rating in ex ante implicit premiums focus on restructuring capital requirements. Such proposals have been floated by the big four federal depositinstitution regulators and have found substantial industry support. To be maximally effective, risk-rated capital requirements must employ parameters that are based on market valuations of the net riskiness of deposit-institution positions and must define capital in a market-value sense.

Risk-rated explicit premiums are neither easier nor harder to develop than risk-rated capital requirements. Ideally, the combination of monitoring costs and premiums of various kinds would at the margin just exhaust the reduction in institutional financing costs generated by the federal guarantee. Using covenants to minimize residual incentive incompatibility, private guarantors use bond-market information to price their services in roughly this way. While useful, agency proposals to impose different implicit and explicit charges on clients judged to have "normal" and "above-normal" riskiness can at best only partially establish this condition.

The incentive reforms treated so far address conflicts of interest between insurers and deposit institutions. To complete the task of reform, it is necessary also to make regulators and elected politicians more accountable to the taxpayer. This requires making it easier for 
taxpayers to recognize poor regulatory performance by reducing regulators' power to suppress information relevant for assessing the quality of agency performance. This end would be promoted by any or all of four broadly procompetitive programs: (1) requiring market-value accounting for insurer liabilities; (2) permitting customers and institutions to compare examination ratings with parallel assessments made by private rating agencies; (3) testing the pricing of deposit-insurance coverages for representative samples of institutions in private markets for reinsurance; and (4) opening up competition for basic coverages between the FDIC and FSLIC and for supplementary coverages between these institutions and private providers.

How hard agencies and politicians resist each of these changes reflects not only how difficult it might appear administratively to effect the proposed change in procedures but also how much improved taxpayer scrutiny would impinge on their freedom of action. Each program would let taxpayers judge whether government or private regulatory mechanisms were doing (or could do) a better or worse job of monitoring, pricing, and disciplining deposit-institution risktaking. Such information would improve politicians' ability to oversee agency operations and force them to face up to and to acknowledge the costs of overly bountiful approaches to insolvency resolution. If making these costs public proves insufficient to avoid inappropriate bailouts, voters could go so far as to introduce statutory restraints on the extent to which insurers or the Federal Reserve could advance funds -- in the absence of regional or national crisis -- to an economically insolvent firm.

\section{The Current Impasse Is Political Not Economic}

Policymakers often claim that economics fails to offer answers to difficult real-world problems. At least in the case of deposit-insurance reform, the problem for economists is not an absence of answers, but an absence of convincing research on how to assemble a minimally disruptive package of effective subsystem reforms.

In the arena of policy research, the predominant problem is the absence of answers that are politically painless. Society and its elected representatives have a tendency to deny and to cover 
up painful tensions. Developing the will to confront and resolve hard issues may be regarded as a higher-order problem that takes precedence over any particular set of substantive issues and helps to explain the strength of forces tending to maintain the status quo.

The distributional pattern of deposit-insurance costs and benefits create winners and losers. Underestimating and hiding the costs helps winners to keep losers from banding together in full force to demand reform. In the case of deposit insurance, the biggest winners are government officials whose jobs are made easier and high-flying deposit institutions that force deposit insurers into funding their risky plays at subsidized rates. Foremost among the losers are those that backstop the insurers: ordinary taxpayers and institutions that compete for business with these high-flying firms. As the product lines of deposit institutions extend into more and more activities, aggrieved competitors increasingly include not only well-managed and wellcapitalized deposit institutions, but nondepository firms of various kinds -- especially insurance companies, securities firms, and real-estate companies.

Defects in contemplated information reporting systems and in related closure options stand out as weak links in reform packages currently being pushed by U.S. authorities. The failure of industry trade associations to focus criticism on these glaring weaknesses testifies to their members' short-sighted concern for preserving near-term subsidies even in the face of their firms' expanding long-run exposure to loss in a deposit-insurance crisis. As long as healthy institutions hold so myopic a view, political support for meaningful reform in accounting requirements or insolvency criteria may have to await a crisis. 


\section{SELECTED BIBLIOGRAPHY}

Aharony, Joseph, and Itzhak Swary. 1983. "Contagion Effects of Bank Failures; Evidence from Capital Markets." Journal of Business (July): 305-22.

American Enterprise Institute. 1985. Proposals for Reform of the Deposit Insurance System. Washington: AEI Legislative Analyses Series.

Avery, Robert B., Gerald A. Hanweck, and Myron L. Kwast. 1985. "An Analysis of Risk-Based Deposit Insurance for Commercial Banks." Proceedings of a Conference on Bank Structure and Competition. Chicago: Federal Reserve Bank of Chicago: 217-250.

Barnett, Robert E.; Horvitz, Paul M.; and Silverberg, Stanley C. 1977. "Deposit Insurance: The Present System and Some Alternatives." Banking Law Journal 94 (April): 304-332.

Barth, James R., R. Dan Brumbaugh, Jr., Daniel Sauerhaft, and George H.K. Wang. 1985. "Thrift-Institution Failures: Causes and Policy Issues." Proceedings of a Conference on Bank Structure and Competition. Chicago: Federal Reserve Bank of Chicago: 184-216.

, R. Dan Drumbaugh, Jr., and Daniel Sauerhaft. 1986. "Failure Costs of Government-Regulated Financial Firms: The Case of Thrift Institutions." Washington: FHLBB (mimeographed, June).

Batlin, Carl. 1983. "Interest Rate Risk, Prepayment Risk, and the Futures Market Hedging Strategies of Financial Intermediaries." Journal of Futures Markets 3 (Summer): 177-184.

Belton, Terrence M. 1985. "Risk-Based Capital Standards for Commercial Banks." Washington: Board of Governors of Federal Reserve System (unpublished, Sept.).

Bennett, Barbara. 1986. "Off Balance Sheet Risk in Banking: The Case of Standby Letters of Credit." Economic Review, Federal Reserve Bank of San Francisco, (Winter): 19-29.

Bennett, Dennis E., Roger D. Lundstrom, and Donald G. Simonson. 1986. "Estimating Portfolio Net Worth Values and Interest Rate Risk in Savings Institutions." Proceedings of a Conference on Bank Structure and Competition, Chicago: Federal Reserve Bank of Chicago: 323-346.

Benston, George J. 1973. "Bank Examination." The Bulletin of the Institute of Finance, Graduate School of Business Administration, New York University nos. 89-90 (May).

, and John Tepper Marlin. 1974. "Bank Examiners' Evaluation of Credit: An Analysis of the Usefulness of Substandard Loan Data." Journal of Money, Credit, and Banking 6 (February): 23-44.

- 1983. "Deposit Insurance and Bank Failures." Economic Review, Federal Reserve Bank of Atlanta (March): 4-17.

- 1984. "Financial Disclosure and Bank Failure." Economic Review, Federal Reserve Bank of Atlanta (March). 
, Robert A. Eisenbeis, Paul M. Horvitz, Edward J. Kane, and George G. Kaufman, Perspectives on Safe \& Sound Banking: Past, Present, and Future. MIT Press for the American Bankers Association, 1986.

Bierwag, G.O., and George G. Kaufman. 1983. "A Proposal for Federal Deposit Insurance with Risk Sensitive Premiums." Occasional paper no. 83-3. Chicago: Federal Reserve Bank of Chicago (March).

Black, Fisher; Miller, Merton; and Posner, Richard. 1978. "An Approach to the Regulation of Bank Holding Companies." Journal of Business 51 (July): 379411 .

Bovenzi, John F., James A. Marino, and Frank E. McFadden. 1983. "Commercial Bank Failure Prediction Models." Economic Review, Federal Reserve Bank of Atlanta 68 (November): 14-26.

and Lynn Nejezchleb. 1985. "Bank Failures: Why Are There So Many?" Issues in Bank Regulation 8 (Winter): 54-68.

Boyd, John H., Gerald Fanweck, and Pipat Pithyachartyakul. 1980. "Bank Holding Company Diversification." Proceedings of a Conference on Bank Struture and Competition, Federal Reserve Bank of Chicago: 105-121.

Brooks, Thomas A., and Vartanian, Thomas P. 1982. Thrifts Acquisitions and Supervisory Problems: The F.D.I.C. and F.H.L.B.B. Speak. New York: Law \& Business/Harcourt Brace Jovanovich.

Buser, Stephen A., Andrew H. Chen, and Edward J. Kane. 1981. "Federal Deposit Insurance, Regulatory Policy, and Optimal Bank Capital." Journal of Finance (March): 51-60.

Campbell, Tim S. 1983. "A Theory of Rating Agencies: Pricing, Quality, and Market Structure." (unpublished, October).

Carroll, Evelyn F., Nick A. Kalambokidis, and Jane A.G. Kise. 1986. "Deposit Insurance, Capital Regulation, and Bank Risk." Proceedings of a Conference on Bank Structure and Competition. Chicago: Federal Reserve Bank of Chicago: 287-310.

Chase, Samuel. 1971. "The Bank Holding Company as a Device for Sheltering Banks from Risk." Proceedings of a Conference on Bank Structure and Competition, Chicago: Federal Reserve Bank of Chicago.

, and Donn L. Waage. 1983. "Corporate Separateness As a Tool of Bank Regulation." Prepared for the Economic Advisory Committee of the American Bankers Association, Washington, D.C.

Chessen, James. 1986. "Off-Balance-Sheet Activity: A Growing Concern?" Regulatory Review, FDIC (May): 1-15.

Conover, C.T. 1984. "Testimony" in U.S. Congress, Subcommittee on Financial Institutions Suspension, Regulation and Insurance of the Committee on Banking, Finance and Urban Affairs, Inquiry into Continental Illinois Corp. and Continental Illinois National Bank: Hearings, Sept. 18 and 19 and Oct. 4, 1984, 91-111, 98th Congress, 2nd Session: 287-88.

Duett, Edwin H., Jr., John M. Harris, and Joseph F. Sinkey, Jr. 1986. "The Valuation of Deposit Insurance Using Alternative Option-Pricing Models." Presented at Financial Management Association Meetings (October). 
Eisenbeis, Robert. 1983a. "Bank Holding Companies and Public Policy." In George J. Benston, ed., Financial Services: The Changing Institutions and Government Policy, Pp. 127-155. Englewood Cliffs, N.J.: Prentice-Hall.

- 1983b. "How Bank Holding Companies Should be Regulated." Economic Review, Federal Reserve Bank of Atlanta (January).

- 1983c. "Bank Holding Companies and Public Policy," in Financial Services: The Changing Institutions and Government Policy, ed. by George J. Benston, Englewood Cliffs, N.J.: Prentice Hall, Inc.

Ely, Bert. 1985. "Yes--Private Sector Depositor Protection is a Viable Alternative to Federal Deposit Insurance" Proceedings of a Conference on Bank Structure and Competition, Chicago: Federal Reserve Bank of Chicago: 338-353.

- 1986a. "Private Sector Depositor Protection is Still a Viable Alternative to Federal Deposit Insurance." Issues in Bank Regulation, 9 (Winter): $40-47$.

- 1986b. "Bailing Out the Federal Savings and Loan Insurance Corporation." (unpublished, June).

England, Catherine. 1986. "A Case for Tiered Deposit Insurance." Issues in Bank Regulation, 9 (Winter): 30-33.

Federal Deposit Insurance Corporation. 1983. Deposit Insurance in a Changing Environment. A Study Submitted to Congress by the Federal Deposit Insurance Corporation. Washington, D.C.

Corporation: The First Fifty Years. Washington, D.C.: 33-53.

- 1984. Federal Deposit Insurance

Federal Home Loan Bank Board. 1982. Revised Report of the Interoffice Task Force on Market Value Accounting. Washington, D.C. (October 8, unpublished).

- 1983. Report of the Expanded Task Force on Current Value Accounting, Washington, D.C. (April 12 unpublished).

- 1983. Agenda for Reform. A Report on Deposit Insurance to the Congress from the Federal Home Loan Bank Board. Washington, D.C.: U.S. Government Printing Office.

Federal Reserve System. 1985. "Policy Statement Regarding Risks on Large-Dollar Wire Transfer Systems." (May 17).

Flannery, Mark J., and Christopher James. 1984. "The Effect of Interest Rate Changes on the Common Stock Returns of Financial Institutions." Journal of Finance 39 (September): 1141-1153.

Flannery, Mark J., and Jack M. Guttentag. 1980. "Problem Banks: Examination, Identification, and Supervision," in Leonard Lapidus, ed., State and Federal Regulation of Commercial Banks. Washington, D.C.: Federal Deposit Insurance Corporation, vol. 11: $169-226$.

Gilbert, R.A., C.C. Stone, and M.E. Trebing. 1985. "The New Bank Capital Adequacy Standards," Review, Federal Reserve Bank of St. Louis, vo. 67, no. 5 (May): 12-20. 
Golembe, Carter H. 1960. "The Deposit Insurance Legislation of 1933: An Examination of Its Antecedents and Its Purposes." Political Science Quarterly 75 (June): 181-200.

, and David S. Holland. 1983. Federal Regulation of Banking 1983-84. Golembe Associates, Inc.: Washington, D.C.

Guttentag, Jack, and Richard Herring. 1982. "Insolvency of Financial Institutions: Assessment and Regulatory Disposition." In Paul Wachtel, ed., Crisis in the Economic and Financial Structure, Lexington, Mass.: Lexington Books: 99. 126.

Haywood, Charles F. 1986. "Federal Savings and Loan Insurance Corporation: Financial Problems and Prospects.: (unpublished, April).

Horvitz, Paul M. 1975. "Failures of Large Banks: Implications for Deposit Insurance and Banking Supervision." Journal of Financial and Quantitative Analysis 10 (November): 589-601.

- 1983a. "Reorganization of the Financial Regulatory Agencies." Journal of Bank Research 13 (Winter): 245-63.

- 1983b. "The Case Against Risk-Related Deposit Insurance Premiums." Housing Finance Review 2 (July): 253-263.

Humphrey, David B. 1976. "100\% Deposit Insurance: What Would It Cost?" Journal of Bank Research (Autumn): 192-198.

Kanatas, George. 1986. "Deposit Insurance and the Discount Window: Pricing Under Asymmetric Information." Journal of Finance 41 (June): 437-450.

Kane, Edward J. 1981. "Accelerating Inflation, Technological Innovation, and the Decreasing Effectiveness of Banking Regulation." Journal of Finance (May).

- 1984. "Technological and Regulatory Forces in the Developing Fusion of Financial-Services Competition." Journal of Finance 39 (July): $759-772$.

1985. The Gathering Crisis in Federal Deposit Insurance. Cambridge: MIT Press.

- 1986. "Appearance and Reality in Deposit Insurance: The Case for Reform." Journal of Banking and Finance 10 (June): 175-188.

- 1987. "The Dangers of Capital Forbearance: The Case of the FSLIC and Zombie S\&Ls." Contemporary Policy Issues, 5 (January): 77-83.

Kareken, John H. 1983. "Deposit Insurance Reform of Deregulation Is the Cart Not the Horse." Quarterly Review, Federal Reserve Bank of Minneapolis (Spring): $1-9$.

, and Neil Wallace. 1978. "Deposit Insurance and Bank Regulation: A Partial Equilibrium Exposition." Journal of Business (July).

Kaufman, George G. 1984. "Measuring and Management Interest Rate Risk: A Primer." Economic Perspectives, Federal Reserve Bank of Chicago (January/February): 16-29. 
- 1985. "Implications of Large Bank Problems and Insolvencies for the Banking Industry and Economic Policy." Issues in Bank Regulation (Winter): $35-42$.

Lane, William R., Stephen W. Looney, and James W. Wansley, "An Application of the Cox Proportional Hazards Model to Bank Failure." Journal of Banking and Finance 10 (December): 511-531.

Leff, Gary, and Park, J.W. 1977. "The Mississippi Deposit Insurance Crisis." Bankers Magazine 160 (Summer): 74-80.

Litan, Robert E. 1985. "Evaluating and Controlling the Risks of Financial Product Deregulation." Yale Journal on Regulation 3 (Fall): 1-52.

Maise l, Sherman J. (ed.) 1981. Risk and Capital Adequacy in Commercial Banks. Chicago: National Bureau of Economic Research, University of Chicago Press.

Mayer, Thomas. 1975. "Should Large Banks Be Allowed to Fail?" Journal of Financial and Quantita tive Analysis 10 (November): 603-613.

1965. "A Graduated Deposit Insurance Plan." Review of Economics and Statistics 47 (February):

Mayers, David, and Clifford L. Smith, Jr. 1982. Toward a Positive Theory of Insurance. Monograph Series in Finance and Economics. New York: Graduate School of Business Administration, New York University.

McCarthy, Ian S. 1980. "Deposit Insurance: Theory and Practice." IMF Staff Papers 27 (Sept.): 578-600.

McCulloch, J. Huston. 1981. "Interest Rate Risk and Capital Adequacy for Traditional Banks and Financial Intermediaries," in Maisel (1981): 223-48.

- 1985. "Interest-Risk Sensitive Deposit insurance Premia: Stable-ACH Estimates." Journal of Banking and Finance 9 (March): 137-56.

Meltzer, Allen H. 1967. "Major Issues in the Regulation of Financial Institutions." Journal of Political Economy, Supplement (August): 482-501.

Merton, Robert C. 1978. "On the Cost of Deposit Insurance When There Are Surveillance Costs." Journal of Business 51 (July): 439-452.

Miller, Randall J. 1980. "On the Cost of Double Supervision for Insured State Chartered Banks," in Leonard Lapidus, ed., State and Federal Regulation of Commercial Banks, vol. II, Washington, D.C.: Federal Deposit Insurance Corporation: $375-415$.

Murphy, Neil B. 1979. "Disclosure of the Problem Bank Lists: A Test of the Impact." Journal of Bank Research (Summer): 88-96.

Peltzman, Samuel. 1970. "Capital Investment in Commercial Banking and Its Relationship to Portfolio Regulation." Journal of Political Economy, (January/February): 1-26.

Pesando, James E. 1985. "Deposit Insurance and the Incentive for Excessive RiskTaking." Toronto: University of Toronto (unpublished). 
Pettway, Richard H. 1976. "Do Banks Overbid When Acquiring Failed Banks?" Financial Management 14 (Summer): 5-15.

, and Joseph F. Sinkey, Jr. 1980. "Establishing On-Site Bank Examination Priorities: An Early-Warning System Using Accounting and Market Information." 35 Journal of Finance (March): 137-150.

Phillips, Almarin. 1985. "Changing Technology and Future Financial Activity," in Handbook for Banking Strategy, ed. by Richard C. Aspinwall and Robert A. Eisenbeis. New York: John Wiley and Sons, Inc.: 125-148.

Pyle, David H. 1984. "Deregulation and Deposit Insurance Reform." Economic Review, Federal Reserve Bank of San Francisco (Spring): 5-15.

- 1983. "Pricing Deposit Insurance: The Effects of Mismeasurement." Unpublished manuscript, Federal Reserve Bank of San Francisco and University of California, Berkeley (October).

Revell, J.R.S. 1983. Banking and Electronic Fund Transfers. Paris: Organization for Economic Cooperation and Development.

Ronn, Ehud I., and Avinash K. Verma. 1986. "Pricing Risk-Adjusted Deposit Insurance: An Options-Based Model." Journal of Finance 41 (September): $871-895$.

Rose, John T. 1978. "The Effect of the Bank Holding Company Movement on Bank Safety and Soundness," in The Bank Holding Company Movement to 1978: A Compendium. Study by the staff of the Board of Governors of the Federal Reserve System (September).

Rosenblum, Harvey, and Christine Pavel. 1985. "Banking Services in Transition: The Effects of Nonbank Competitors," in Handbook for Banking Strategy, ed. by Richard C. Aspinwall and Robert A. Eisenbeis. New York: John Wiley and Sons, Inc.: 203-266.

Rothschild, Michael, and Stiglitz, Joseph. 1976. "Equilibrium in Competitive Insurance Markets: An Essay on the Economics of Imperfect Information." Quarterly Journal of Economics 90 (November): 629-649.

Sachs, Jeffrey D. and Steven C. Kyle. 1985. "Developing Country Debt and the Market Value of Large Commercial Banks." Cambridge, Mass.: National Bureau of Economic Research Working Paper No. 1470.

Santomero, Anthony M. 1983. Current Views of the Bank Capital Issue. Washington: Association of Reserve City Bankers.

Scott, Kenneth W., and Mayer, Thomas. 1971. "Risk and Regulation in Banking: Some Proposals for Deposit Insurance." Stanford Law Review 23 (May): 857902.

Short, Eugenie D., and Gerald P. O'Driscoll, Jr. 1983. "Deregulation and Deposit Insurance." Economic Review, Federal Reserve Bank of Dallas (September): $11-22$.

, and Frank D. Berger. 1985. "Recent Bank Failures: Determinants and Consequences." Proceedings of a Conference on Bank Structure and Competition, Federal Reserve Bank of Chicago. 
Shull, Bernard. 1980. "Federal and State Supervision of Bank Holding Companies," in Leonard Lapidus, ed., State and Federal Regulation of Commercial Banks, vol. II, Washington, D.C.: Federal Deposit Insurance Corporation: 271-375.

- 1983. "The Separation of Banking and Commerce: Origin, Development, and Implications for Antitrust." The Antitrust Bulletin XXVII (Spring): 255-79.

Sinkey, Joseph F., Jr. 1985. "Regulatory Attitudes Toward Risk." In Richard C. Aspinwall and Robert S. Eisenbeis, eds., The Banking Handbook, New York: Wiley: $347-380$.

- 1979. Problem and Failed Institutions in the Commercial Banking Industry. Greenwich, Conn.: JAI Press.

Sosin, Howard B. 1980. "On the Valuation of Federal Loan Guarantees to Corporations." Journal of Finance, 35 (December): 1209-1221.

Spong, Kenneth, and Hoenig, Thomas. 1979. "Bank Examiner Classifications and Loan Risk." Economic Review, Federal Reserve Bank of Kansas City (June): $15-25$.

Sprague, Irvine H. 1986. Bailout: An Insider's Account of Bank Failures and Rescues. New York: Basic Books.

Swary, Itzhak. 1985. "Continental Illinois Crisis: An Empirical Analysis of Regulatory Behavior." Working paper, Hebrew University of Jerusalem (January).

Sweeney, Richard J., and Arthur D. Warga. 1986. "The Pricing of Interest-Rate Risk: Evidence from the Stock Market." Journal of Finance, 41 (June): 393410.

Thomson, James B. 1987. "The Use of Market Information in Pricing Deposit Insurance." Journal of Money, Credit and Banking (forthcoming, August).

U.S. Congress, House Committee on Banking and Currency, Hearings. 1984. Inquiry Into Continental Illinois Corp. and Continental Illinois National Bank: Hearings, House of Representatives, Subcommittee on Financial Institutions, Supervision, Regulation and Insurance of the Committee on Banking, Finance and Urban Affairs, 98th Congress, 2nd Session (September 18-19 and October 4).

, House Committee on Government Operations. 1984a. Federal Home Loan Bank Board Supervision and Failure of Empire Savings and Loan Association of Mesquite, Tex., Forty-Fourth Report, 98th Congress, 2nd Session, House Report 98-953 (August 6).

, House Committee on Government Operations. 1984b. Federal Regulation of Brokered Deposits in Problem Banks and Savings and Loan Institutions, Fifty-Second Report, 98th Congress, 2nd Session, House Report 98-1112 (September 28).

, Senate Committee on Banking, Housing, and Urban Affairs. 1986. Deposit Insurance Reform and Related Supervisory Issues, Hearings (January 22, March 4, and March 13). Washington, D.C.

Subcommittee on Financial Institutions, Supervision, Regulation and Insurance of House Committee on Banking, Finance, and Urban Affairs. 
1985. Financial Condition of the Bank and Thrift Industries, Hearings (September 11, 12,18, and 19; October 2, 3, and 17). Washington, D.C.

United States League of Savings Institutions. 1986. Report of Task Force on FSLIC Issues: A Comprehensive Plan for the FSLIC. Washington, D.C.

U.S. General Accounting Office. 1984. Federal Financial Institutions Examination Council Has Made Limited Progress Toward Accomplishing Its Mission. Report to the Congress of the United States by the Comptroller General. GAO/GGD-84-4: Washington, D.C. (February 3)

Potential Demands on the FSLIC Insurance
(February).

1986b. Thrift Assistance: Industry Restructuring and the Net Worth Certificate Program--Update. Washington, D.C. (April).

Wu, Hsiu-Kwang. 1969. "Bank Examiner Criticisms, Loan Defaults and Bank Loan Quality." Journal of Finance, 24 (September): 667-705. 